\title{
Recessions, Budget Deficits, And Austerity: A Comment On The U.S. And European Economies
}

Alex J. Kondonassis, Ph.D., University of Oklahoma, USA

\begin{abstract}
We have seen that both the U.S. and the European Union have experienced a serious recession in recent years. Some of the results of these economic difficulties include a rise in unemployment and an increase in budget deficits and national debts. This paper discusses the likely outcome of policies instituted by U.S. and European leaders to this economic situation.
\end{abstract}

Keywords: Great Recession; Austerity Measures; European Union; Economic Development

\section{INTRODUCTION}

$\mathrm{n}$ the last few years the U.S. economy and a number of Eurozone countries have experienced a recession.
One of the results of the recessions has been an increase in their budget deficits and national debts. Both
in the U.S. and in Europe policies of austerity have gained momentum. It is questionable however, that in
periods of recession austerity leading to reductions of aggregate spending is the answer. It can be argued that
emphasis on growth may be a preferable alternative.

A look at the U.S. economy in 1998, 1999, 2000, and 2001 we find that because of strong growth unemployment was about 4 percent and budget surpluses characterized all four years.

In the case of Europe the countries with most difficulties are peripheral countries of the European Union, e.g., Italy, Spain, Portugal, Greece. This raises the question, on whether the integration of small and large countries and of different standards of living was a wise move. Concerns about this issue led the Single European Act of 1986 to emphasize the need for social and economic cohesion. An outcome of this was the use of structural funds primarily to the peripheral countries. Yet, we know that social value changes and economic development take time.

Germany, the largest and richest country of the Union seems to be playing a dominant role currently in urging austerity for the peripheral countries which have large deficits and debts. Suggestions that the European Central Bank act as a bank of last resort by lending directly to the various governments in need and/or the creation of Eurobonds have been rejected by the Eurozone leadership. Leaders in Brussels have also voted recently for strict budget criteria for the Eurozone members.

Among the peripheral countries in difficulty Greece is the worst case scenario. The Greek economy has shrunk by 7.5 per cent in the fourth quarter of 2011 and young people in Greece experience unemployment of 51 per cent. On February 9, 2012 the Greek government was able to convince private bondholders to accept a 75 per cent loss in the face value of bond holdings. The result of this was a reduction in Greece's debt by 100 billion Euros. At the same time the Eurozone and IMF are expected to provide Greece with a stopgap package of 130 billion Euros. These developments do not mean that Greece is out of the woods. Its indebtedness is now with Europe and the IMF. It's debt to GDP ratio would still be 151 per cent in 2012, the highest in Europe. The challenges facing the new government resulting from the elections of June 17, 2012 are staggering. 
Other countries, e.g., Italy and Spain are also facing economic declines and are potentially candidates for bailouts. It is because of this possibility that the Managing Director of the IMF has been urging Europe to raise at least $\$ 1$ trillion in emergency funds.

At this point, it is not clear how the European crisis will be resolved. Perhaps two basic questions may be raised: 1) would the strongest economies be willing to help more effectively the peripheral countries in trouble? 2) Would the "failed" policy of austerity in depressed economies be changed by more emphasis on growth? At present, it appears that a balanced policy including more emphasis on demand side economics makes sense in both the USA and Europe.

\section{THE U.S. ECONOMY}

The U.S. economy, notwithstanding its spectacular growth in the $19^{\text {th }}$ Century, it experienced 7 booms and busts during that period. No apparent government intervention took place. It is well known that the most pronounced downturn in the U.S. was that of the 1930s.

Many reforms and institutional changes resulted from the experience. Demand side economics was practiced and an increased aggregate spending related to World War II brought the U.S. economy out of the depression. Several decades of satisfactory aggregate performance followed.

Beginning in the 1980s reforms appear to have lost their steam. The Wall Street learned to evade the rules and banks became able to perform outside the regulatory oversight. Speculation on equities and housing took place. A widely spread view took hold that investment in real estate was safe and the same was thought of securities built out of mortgages. Prices of assets rose. A euphoria characterized investment banks, insurers and money markets. A bubble was in the making. It ended when the supply of assets exceeded demand. Confidence that prices will keep rising vanished and borrowing became difficult. The boom became a bust; borrowers were asked to put up more collateral and everyone moved to safer assets. Banks curtailed lending and brought a crunch. A result of the bust was that many banks went under, a major institution, Lehman Brothers collapsed and unemployment rose to about $10 \%$ of the labor force. This was the recession of 2007-2008. (Kondonassis, 2011)

As the crisis worsened, the Federal Reserve made large amounts of credit available, limited demand side stimuli programs were tried, Chrysler and General Motors as well as financial institutions were bailed out.

A major consequence of the depression of the 1930s was the use of deficit spending as an anti-depression demand side measure. This measure was continued to be employed in good times and in not so good times. As a result the national debt used to finance them has increased. Both have increased in coping with the recession of 2007-2008 to the point that the budget deficit as a per cent of GDP rose to about 10 per cent and the national debt to about 99 per cent of G.D.P. These recent developments have become serious concerns for the U.S. economy. U.S. politicians are debating solutions. The options include raising revenues via taxation and/or practicing austerity by reducing expenditures in government financed programs.

Given the recession, timing is important. It is also important to keep in mind that austerity measures may negatively affect economic growth which is a means of combatting a recession and unemployment. It is instructive to note that the U.S. economy, largely because of, strong growth experienced 4,5 per cent, 4.2 per cent, 4 per cent and 4.7 per cent unemployment and budget surpluses of $\$ 69.3$ billion, $\$ 125$ billion, $\$ 236$ billion and 128 billion all in 1998, 1999, 2000, and 2001 respectively. (Economic Report of the President, 2011).

The lesson is that economic growth can be an effective means of raising revenue and reducing budget deficits. Yet austerity seems to have strong support in the U.S., which explains why only limited stimuli were used. Financial Institutions and General Motors and Chrysler bailouts seem to have helped in the gradual recovery of the U.S. economy with unemployment dropping to about 8 per cent of the labor force in early 2012. 


\section{THE EUROPEAN UNION}

Europe has not remained immune to happenings in the U.S. economy. In fact several Eurozone countries have experienced/experiencing recessions.

It will be remembered that 27 European countries have become members of the European Union but only 17 have joined the Eurozone. The Maastricht Treaty which established the criteria for joining the Eurozone in 1999 provided that eligibility depended on: 1). An inflation rate not more than 1.5 per cent higher than the three lowest rates among the members; 2). A budget deficit not higher than 3 per cent of GDP; 3). A long term interest rate no more than 2 per cent higher than the European Union's three lowest; and 4). A national debt not higher than 60 per cent of GDP. (Kondonassis, 2011)

With regard to the budget deficit and national debt criteria several Eurozone countries have now difficulties in meeting them. For instance, the budget deficit as a per cent of GDP was 8.6 per cent, 4.0 per cent and 8.2 per cent for Greece, Italy and Spain respectively in 2011. The average for the Eurozone was 4.1 per cent in 2011. The unemployment rate was 18.2 per cent, 8.6 per cent and 22.9 per cent for Greece, Italy and Spain respectively in 2011. For the Eurozone the average was 10.3 per cent in 2011. (The Economist, January 28, 2012)

For some Eurozone countries the national debt has been more than twice as high as the Maastricht criterion of 60 per cent of GDP.

Pressures have been exerted by the European Union leadership on countries like Greece, Italy, Spain and Portugal to reduce their budget deficits and national debts. The emphasis has been on austerity measures including reduction in wages, pensions, other government spending and raising revenues via taxation. Italy, under the leadership of the new Prime Minister, Mr. Monti, is engaged in a major reform program designed to reduce its debt which is one of the highest in the European Union. However, rising borrowing costs is one of Italy's major problems. Spain has discovered that its deficits in 2011 are higher than anticipated partly because regional governments did not meet their goals. Spain's unemployment is one of the highest in the European Union. Given continuing difficulties Spain is a candidate for a bailout and has just received 100 billion Euros to assist its banks which are facing mounting difficulties.

The Spanish economy is also experiencing a second recession and a housing bust has led to hundreds of thousands of real estate repossessions with many more facing default. The economy as a whole may need a major rescue.

The European Union and the IMF have reported that Portugal has made good progress toward cutting its deficits and yet the economy is contracting with the national debt expected to rise from 107 per cent of GDP to 118 per cent of GDP. Greece represents the worst case scenario so far as the European Union and the IMF are concerned. Apart from the inexcusable behavior of Greek politicians and the use of questionable accounting data, the Greek economy is clearly in bad shape. GDP has contracted by 15 per cent since 2008 and unemployment is 21.9 per cent. (The Economist, May 5, 2012) in May 2012.

The European Union and the IMF have made the 130 billion Euros bailout that Greece is to receive subject to serious reforms including wage cuts, layoffs of civil servants, privatization of state properties, weakening of unions and deregulation. The bailout is also contingent on Greece's reduction of private debts. Restructuring of Greece's private debt has targeted the reduction of the face value of bonds to less than half their face value. The aim is to bring "eventually" the total debt of Greece to about 120per cent of GDP, although currently it appears to be around 160 per cent of GDP. Both of the above transactions have given Greece a "short lived" period of relief. However, the results of the "May 6" elections raised anew questions about Greece's future in the Eurozone. An exit cannot be ruled out with serious repercussions to Greece and the European Union. The results of the June 17, 2012 election indicate that Greece will stay in the Eurozone, at least for the time being, but the challenges facing the new government will be immense. 
In an editorial article on February 18, 2012 the New York Times argues that the austerity measures that the leadership of the European Union has adopted have failed. Imposing austerity in countries like Greece, Spain, Italy, and Portugal has deepened their recessions and there is no way these countries can go back to growth. Punishment of the people in these countries is no answer to the economic crisis facing them, the New York Times adds.

Reinforcing the view that austerity is not the answer to the economic difficulties facing several of the peripheral countries. Paul Krugman argues that trying to eliminate deficits when the economy is in trouble is a recipe for a depression. He further argues "profligacy is bad; so is mistimed austerity". Lawrence Summers in a March 9, 2012 conference sponsored by the Academie Diplomatique Internationale in Paris claimed that Europe lacked a "viable growth model". There is a tendency for the avatars of austerity to neglect the effect on growth. Although the fears of the Greek economy have subsided (at least temporarily) he sees continuing concerns for countries such as Spain, Portugal and Italy. He raises the question whether Germany and other healthier European countries should be emphasizing growth in their own countries to offset for the need to reduce debts in Southern Europe.

In recent weeks even a conservative lending institution like the IMF has been critical of the European leadership for cutting budgets too quickly resulting in adverse effects on growth. In a recent meeting of the G8 in Camp David a strong endorsement was promulgated in favor of a policy stressing balance between austerity and growth. On the other hand, the advocates of austerity measures claim that cutting spending and balancing budgets produce confidence on the management of the public sector which in turn helps economic growth.

While the debate on austerity vs. growth may continue, a few other proposals have been advanced which may influence the future functioning of the Eurozone. They are worth a brief examination as follows:

To guard against the lack of market confidence and to prevent the spread of fiscal contagion in the Eurozone, the head of OECD Angel Curria said in Brussels on March 27, 2012 that a financial firewall of about 1 trillion Euros must be established. An increase in the financial firewall has been seconded by the Managing Director of the IMF. In a meeting of the IMF and the World Bank in Washington DC in April 2012 the Managing Director of the IMF, Christine Lagarde, announced that the IMF lending capacity increased by new commitments of $\$ 430$ billion, a welcome development given the possible increased financial needs of Eurozone countries.

It is generally known that a major issue facing the countries of the European Union is lack of convergence of fiscal policies. To move toward correction in March 2012, 25 of the 27 countries of the European Union have signed a fiscal compact proposing greater fiscal discipline. Chancellor Merkel is the champion of this proposal. The proponents of a strict fiscal discipline go further arguing in favor of the possibility of the European Union moving toward political union. It is perhaps a question of timing yet the same people object to the idea that the European Central Bank became a bank of last resort lending to the governments of the European Union as it did in December 2011 and again in March 2012 at 1 per cent interest for three years to commercial banks in the European Union.

The issuance of Eurobonds as a means of establishing a fiscal union is another proposal to which the European leadership is opposed. The new president of France, Mr. Hollande, argues in favor and so is the president of the World Bank who is suggesting some sort of partial Eurobonds.

Opposition to both of the above proposals seems to be based on the fear for inflation and concern about increased burdens on the more prosperous countries of the Union.

The European Union comprises countries of high productivity in the North and low productivity in the South. The ability of the South to compete with a devaluation, which is not allowed, is problematical. The experience of the peripheral southern countries has been that of large trade deficits. For instance while countries like Greece, Spain and Italy experienced a trade deficit of 26.3 billion Euros, 66.3 billion Euros and 51.8 billion Euros respectively in the last 12 months of 2011 to February 2012. Germany had a trade surplus of 205 billion Euros during the same period (The Economist, May 5, 2012). In the absence of devaluation of their currency the low productivity peripheral countries try to make adjustments by relying on wages and employment. 
This situation facing the peripheral countries reminds us of discussions from the theory of economic integration (Viner, 1950; Lipsey, 1960) that it is not necessarily wise to put together countries of different size and different standards of living. The single European Act of 1986 recognized the potential problem and urged that social and economic cohesion become a goal of the European Union. The approval of substantial amounts of structural funds to the peripheral countries was an outcome of this goal (Kondonassis, 2011). Yet it must be realized that changes on values and infrastructure building for development are not overnight events. Large disparities in productivity continue among the countries of the European Union. This reality is perhaps a major reason why there is talk about the Euro's dissolution, Is the Euro in serious trouble? No one can say for sure whether the Euro would survive. A great deal depends on how the Eurozone countries resolve the challenges facing them including the possible expansion of the role of the European Central Bank, the introduction of a bank insurance program and the implementation of the fiscal impact. In this regard two hopeful developments took place on September 12, 2012. The German Constitutional Court supported the European Stability Mechanism (ESM), the Eurozone's rescue fund, and the European Commission proposal to plan for a joint European Bank Supervision. Obviously, these are incremental changes but on the right direction. Additionally, a policy of closer cooperation between the stronger economies of the North and peripheral countries of the South appears to be necessary. Domineering nationalism must be avoided.

\section{CONCLUDING COMMENTS}

We have seen that both the U.S. and the European Union have experienced/experiencing recessions. Some of the results of these economic difficulties include a rise in unemployment and an increase in budget deficits and national debts. The U.S. economy has made a (slow) recovery because of the Federal Reserve policy to engage in quantitative easying in order to restore liquidity as well as because of the limited stimuli programs and the bailouts of financial institutions and auto companies. Europe, on the other hand, has adhered to austerity programs and no attention seems to be given to spending and/or economic growth; at least for the time being.

Given that the U.S. and some European economies, e.g., Spain and Greece, continue to experience high unemployment, it is reasonable to assume that economic recovery is their priority. Austerity measures in the midst of recessions, as stated above, are the wrong policy. We have also learned from the past that if private demand is weak, public demand can be an effective substitute. If recovery is pursued and attained, revenues are likely to rise and budget deficits would tend to decrease. At present it can be argued that what the U.S. and the European economies need is more emphasis on demand side economics and economic growth. Overall a balanced policy has merits.

\section{AUTHOR INFORMATION}

Alex. J. Kondonassis, Ph.D., is a David Ross Boyd Professor of Economics (Emeritus) and Regents Professor of Economics (Emeritus) at The University of Oklahoma, USA. E-mail: matkins@ou.edu

\section{REFERENCES}

1. Cecchini, Paolo. 1992. The European Challenge. Aldershot, England: Wildwood House.

2. Economic Report of the President, 2011 Washington, D.C. United States Printing Office.

3. Kondonassis, A. J., 2011 Global Economic Development. Norman, Oklahoma College of Continuing Education, University of Oklahoma

4. Lipsey, R.C. 1960. The Theory of Customs Unions: A General Survey, Economic Journal.

5. Pescatore, Pierre. 1987. "Some Critical Remarks on the Single European Act". Common Market Law Review.

6. The Economist. January 28, 2002, and May 5, 2012. London

7. Viner, J. 1950. The Customs Union Issue New York: Carnegie Endowment for International Peace. 
NOTES 